\title{
New Record of Paratrichodorus minor (Colbran, 1956) Siddiqi, 1974 and Redescription of $P$. porosus (Allen, 1957) Siddiqi, 1974 (Triplonchida: Trichodoridae) from Citrus unshiu Markovich in Korea
}

\author{
Byeong-Yong Park*, Sun-Nam Park and Jae-Kook Lee
}

Agricultural microbiology Division, National Academy of Agricultural Science, Suwon, 441-707, Republic of Korea

\begin{abstract}
During the survey of plant parasitic nematode of Citrus orchard in Korea, Paratrichodorus minor (Colbran, 1956) Siddiqi is founded from the soil of Citrus unshiu Markovich for the first time in Korea. The body length of females is $428.34 \sim 506.22 \mu \mathrm{m}$ long: $\mathrm{a}=12.08 \sim 22.79, \mathrm{~b}=4.02 \sim 5.02, \mathrm{~V}(\%)$ $=38.46 \sim 60.68$. The excretory pore is located near the base of esophagus. Additionally, the morphological characteristics on P. porosus (Allen, 1957) Siddiqi, 1974 recorded in 1976 on Korea is redescribed in detail.
\end{abstract}

KEY WORDS : Systematics, Trichodoridae, Paratrichodorus minor, Paratrichodorus porosus

\begin{abstract}
초 록 : 감귤 과수원의 식물기생선충을 조사하던 중, 한국미기록 선충인 Paratrichodorus minor가 처음으 로 제주도 감귤과수원 토양에서 발견되었다. Paratrichodorus minor는 크기가 428.34 506.22 $\mu \mathrm{m}$ 이고, $\mathrm{a}=12.08 \sim 22.79, \mathrm{~b}=4.02 \sim 5.02, \mathrm{~V}(\%)=38.46 \sim 60.68$ 이었으며, 배설공(excretory pore)이 후부식도부에 위치하는 특징을 가지고 있다. 또한, 1976년에 한국에서 보고된 P. porosus의 형태적 특징에 관하여 재기술 하였다.

검색어 : 분류, 곧은궁침선충과, Paratrichodorus minor, Paratrichodorus porosus
\end{abstract}

The family Trichodoridae Thorne, 1935 are very important nematodes to damage to the root of the crops as well as vectors of plant virus (Decraemer, 1980). At present, it is reported on Korea that Trichodoridae includes five species in two genera: Trichodorus Cobb, 1893 and Paratrichodorus Siddiqi, 1974 (Choi, 1996). During the survey of plant parasitic nematode of Citrus orchard, an unrecorded species of Paratrichodorus was founded. In this paper, morphological characteristics of the species is described and illustrated in detail. P. porosus (Allen, 1957) Siddiqi, 1974 was recorded in Korea on 1976 (Lee, 1976). Because of the new morphological character and insufficient descriptions on P. porosus, morphological charac- teristics of the species were additionally redescribed in detail.

\section{Material and Method}

The nematode was collected from the soil around the roots of Citrus unshiu Markovich in Jeju province, Korea on 2008. The nematodes extracted by modified Baermann funnel method were fixed in hot $\left(80^{\circ} \mathrm{C}\right)$ TAF fixative and dehydrated by Seinhorst's rapid glycerin method (Hooper, 1986). The specimens of identification were done with a Key made by Decraemer (Decraemer, 1980,

*Corresponding author. E-mail: bypark@rda.go.kr 
1991). Measurements and drawings were made with a microscope equipped with a drawing tube attachment.

\section{Description of Species}

\section{Paratrichodorus minor (Colbran, 1956) Siddiqi,} 1974 , 작은곧은궁침선충

syn. Trichodorus minor Colbran, 1956

Nanidorus minor (Colbran, 1956) Siddiqi, 1974

T. christiei Allen, 1957

P. (N.) christiei (Allen, 1957) Siddiqi, 1974

N. christiei (Allen, 1957) Siddiqi, 1974

P. (N.) obesus (Razjivin \& Penton, 1975)

Rodriquez-M \& Bell, 1978

Measurements: see Table 1.
Female: Body cylindrical and curved ventral after killing by hot fixative. Cuticle smooth and slightly swell from subcuticle. No lateral body pores. Head not set off. Amphids opening slitlike and cup-shaped. Onchiostylet 24.89 $31.44 \mu \mathrm{m}$. Excretory pore located near the base of esophageal. Oesophagus ventral overlapping slightly. No cervical papilla. Vulva a small, transverse slitlike. Vaginal sclerotization not developed and shorter than half of the body width. Spermatica not observed. Tail short, hemispherical.

Male: not founded

Discussion on morphometric characteristics: Morphological characters of this specimens are similar to those of Allen's descriptions(Allen, 1957). However, this specimen is smaller than Siddiqi and Shishida's morphometric data (Shishida, 1979 and Siddiqi, 1963, 1973).

Table 1. Measurement comparison of Paratrichodorus minor

\begin{tabular}{|c|c|c|}
\hline \multirow[b]{2}{*}{ Characters } & \multicolumn{2}{|c|}{ Female } \\
\hline & $\begin{array}{c}\text { Jeju } \\
\mathrm{n}=13\end{array}$ & $\begin{array}{c}\text { Allen (1957) } \\
\mathrm{n}=20\end{array}$ \\
\hline $\mathrm{L}(\mu \mathrm{m})$ & $\begin{array}{c}471.27 \pm 27.86^{\mathrm{a}} \\
(428.34 \sim 506.22)^{\mathrm{b}}\end{array}$ & $460 \sim 710$ \\
\hline Body width $(\mu \mathrm{m})$ & $\begin{array}{c}26.20 \pm 6.56 \\
(19.65 \sim 41.92)\end{array}$ & \\
\hline Neck length $(\mu \mathrm{m})$ & $\begin{array}{c}84.17 \pm 1.65 \\
(82.53 \sim 86.46)\end{array}$ & \\
\hline Onchiostylet length $(\mu \mathrm{m})$ & $\begin{array}{c}29.58 \pm 2.05 \\
(24.89 \sim 31.44)\end{array}$ & $33 \sim 47$ \\
\hline Fore end to excretory pore $(\mathrm{EP})(\mu \mathrm{m})$ & $\begin{array}{c}89.74 \pm 2.27 \\
(87.77 \sim 93.01)\end{array}$ & \\
\hline Anterior ovary $(\mu \mathrm{m})$ & $\begin{array}{c}106.30 \pm 8.99 \\
(90.39 \sim 120.52)\end{array}$ & $16 \sim 24$ \\
\hline Posterior ovary $(\mu \mathrm{m})$ & $\begin{array}{c}92.82 \pm 19.45 \\
(57.64 \sim 111.35)\end{array}$ & $13 \sim 26$ \\
\hline Ratio a & $\begin{array}{c}18.81 \pm 3.37 \\
(12.08 \sim 22.79)\end{array}$ & $15 \sim 20$ \\
\hline Ratio b & $\begin{array}{c}4.47 \pm 0.30 \\
(4.02 \sim 5.02)\end{array}$ & $4.6 \sim 6.0$ \\
\hline Ratio V & $\begin{array}{c}51.97 \pm 9.12 \\
(38.46 \sim 60.68)\end{array}$ & $50 \sim 56$ \\
\hline Fore end to EP/neck length (\%) & $\begin{array}{c}106.61 \pm 0.65 \\
(106.25 \sim 107.58)\end{array}$ & \\
\hline Onchiostylet length/neck length (\%) & $\begin{array}{c}36.18 \pm 1.07 \\
(34.92 \sim 37.5)\end{array}$ & \\
\hline
\end{tabular}

\footnotetext{
${ }^{a}$ mean \pm standard deviation.
}

${ }^{\mathrm{b}}$ range (min $\left.\sim \max \right)$. 

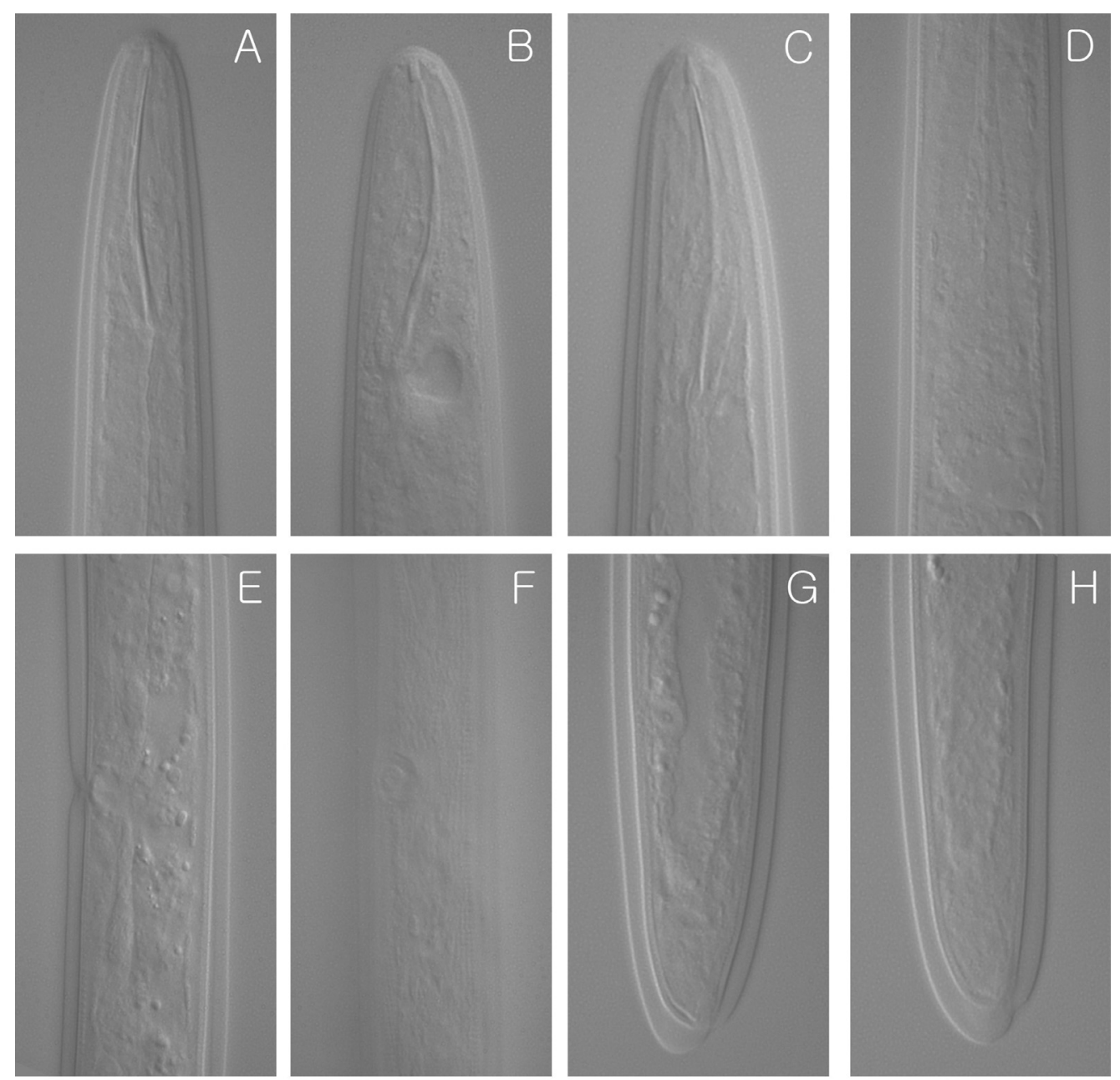

Fig. 1. Photomicrographs of Paratrichodorus minor: A, B, C: Female anterior part; D: Female base of esophagus: E: Female vulva region; F: Lateral view of vulva; G, H: Female tail.

Locality and host: Seoqwipo city, Jeju province (Citrus unshiu Markovich)

It was reported that $P$. minor was founded in various plants and trees (Allen, 1957; Shishida, 1979; Bell et al., 2001; Decraemer, 1991). Also the species was widely distributed in many countries of world. However, the species collected in this time was only founded in one sampling site of Jeju province. So it is assumed that the species is distributed in restricted sites in Korea. To get the distributional state of the species, it is necessary to investigate the distribution of $P$. minor intensively.

Paratrichodorus porosus (Allen, 1957) Siddiqi, 1974 , 배추곧은궁침선충

syn. Trichodorus porosus Allen, 1957
P. (Allotrichodorus) porosus (Allen, 1957) Siddiqi, 1974

A. porosus (Allen, 1957) Siddiqi, 1974

T. bucrius Lordello \& Zamith, 1958

\section{Measurements: see Table 2.}

Female: Body cylindrical, well swelled and cuticle smooth. Lip region set off. Amphids opening slitlike and cup-shaped. Onchiostylet 32.75 56.33 $\mu \mathrm{m}$. Excretory pore located middle of the oesophagus. Oesophagus slightly overlaps intestine ventrally. A pair of ventromedian pores located anterior and posterior to the vulva. Vulva opening small and porelike. Cutinized pieces are small and inconspicuous. The female gonad paired. Spermatica inconspicuous. Tail short, hemispherical. Caudal pores present. 
Table 2. Measurement comparison of Paratrichodorus porosus

\begin{tabular}{|c|c|c|c|}
\hline \multirow[b]{2}{*}{ Characters } & \multicolumn{3}{|c|}{ Female } \\
\hline & $\begin{array}{c}\text { Jeju } \\
\mathrm{n}=25\end{array}$ & $\begin{array}{c}\text { Allen (1957) } \\
\mathrm{n}=16\end{array}$ & $\begin{array}{c}\text { Lee }(1976) \\
n=10\end{array}$ \\
\hline $\mathrm{L}(\mu \mathrm{m})$ & $\begin{array}{c}584.91 \pm 82.14^{\mathrm{a}} \\
(382.91 \sim 772.31)^{\mathrm{b}}\end{array}$ & $460 \sim 770$ & $510(400 \sim 720)$ \\
\hline Body width $(\mu \mathrm{m})$ & $\begin{array}{c}35.60 \pm 4.67 \\
(26.2 \sim 48.47)\end{array}$ & & \\
\hline Neck length $(\mu \mathrm{m})$ & $\begin{array}{c}79.61 \pm 6.58 \\
(64.19 \sim 86.46)\end{array}$ & & \\
\hline Onchiostylet length $(\mu \mathrm{m})$ & $\begin{array}{c}48.13 \pm 4.78 \\
(32.75 \sim 56.33)\end{array}$ & $43 \sim 50$ & $46.0(40.8 \sim 48.2)$ \\
\hline Fore end to excretory pore $(\mathrm{EP})(\mu \mathrm{m})$ & $\begin{array}{c}87.27 \pm 6.25 \\
(72.05 \sim 95.63)\end{array}$ & & \\
\hline Anterior ovary $(\mu \mathrm{m})$ & $\begin{array}{c}146.72 \pm 18.53 \\
(125.76 \sim 188.64)\end{array}$ & $19 \sim 28$ & \\
\hline Posterior ovary $(\mu \mathrm{m})$ & $\begin{array}{c}132.86 \pm 13.91 \\
(110.04 \sim 158.51)\end{array}$ & $12 \sim 25$ & \\
\hline Ratio a & $\begin{array}{c}16.47 \pm 1.53 \\
(14.06 \sim 19.65)\end{array}$ & $15 \sim 25$ & $21.0(16.3 \sim 27.0)$ \\
\hline Ratio b & $\begin{array}{c}4.40 \pm 0.55 \\
(3.28 \sim 5.51)\end{array}$ & $4.1 \sim 5.5$ & $4.6(4.0 \sim 5.3)$ \\
\hline Ratio V & $\begin{array}{c}53.63 \pm 8.20 \\
(39.62 \sim 73.17)\end{array}$ & $53 \sim 58$ & $65.1(50.5 \sim 60.8)$ \\
\hline Fore end to EP/neck length (\%) & $\begin{array}{c}109.76 \pm 3.30 \\
(104.62 \sim 118.18)\end{array}$ & & \\
\hline Onchiostylet length/neck length (\%) & $\begin{array}{c}62.15 \pm 6.20 \\
(54.55 \sim 74.14)\end{array}$ & & \\
\hline
\end{tabular}

${ }^{a}$ mean \pm standard deviation

${ }^{\mathrm{b}}$ range $(\min \sim \max )$
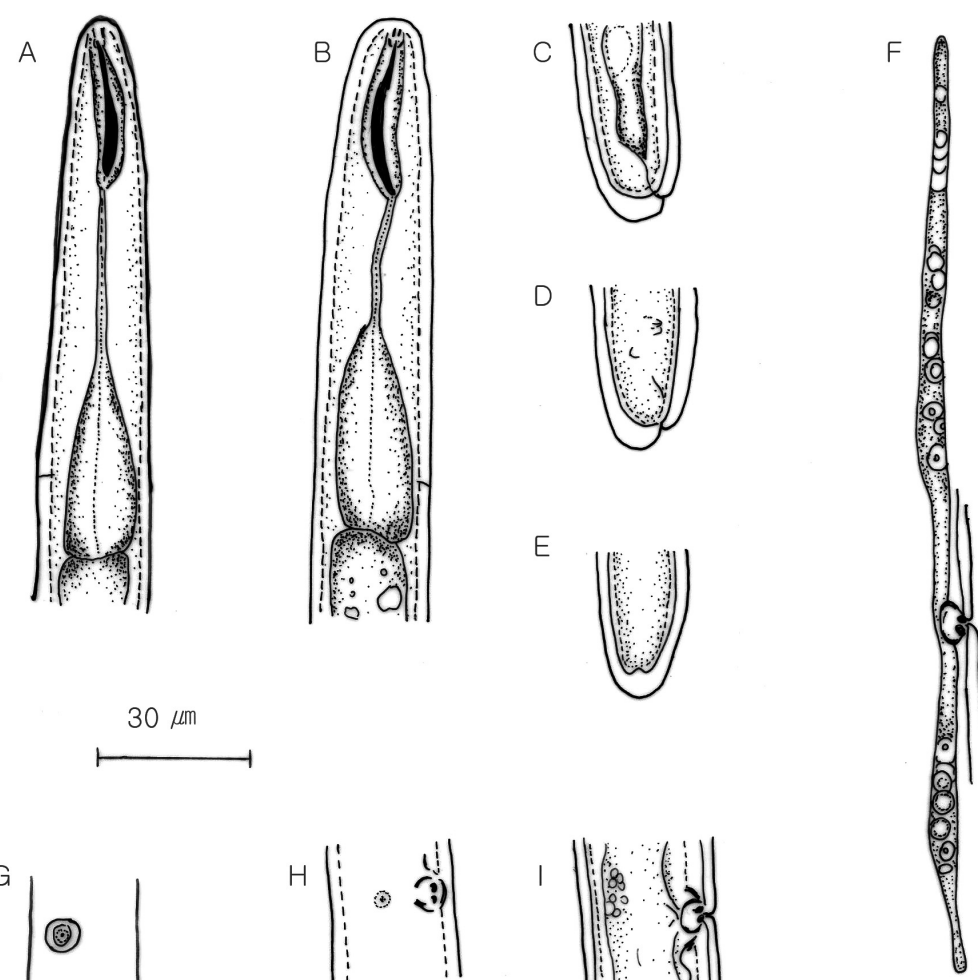

Fig. 2. Diagrams of Paratrichodorus minor: A, B: Female anterior part; C, D, E: Female tail; F: Female gonad; G: Lateral view of vulva; H, I: Vulva region. 

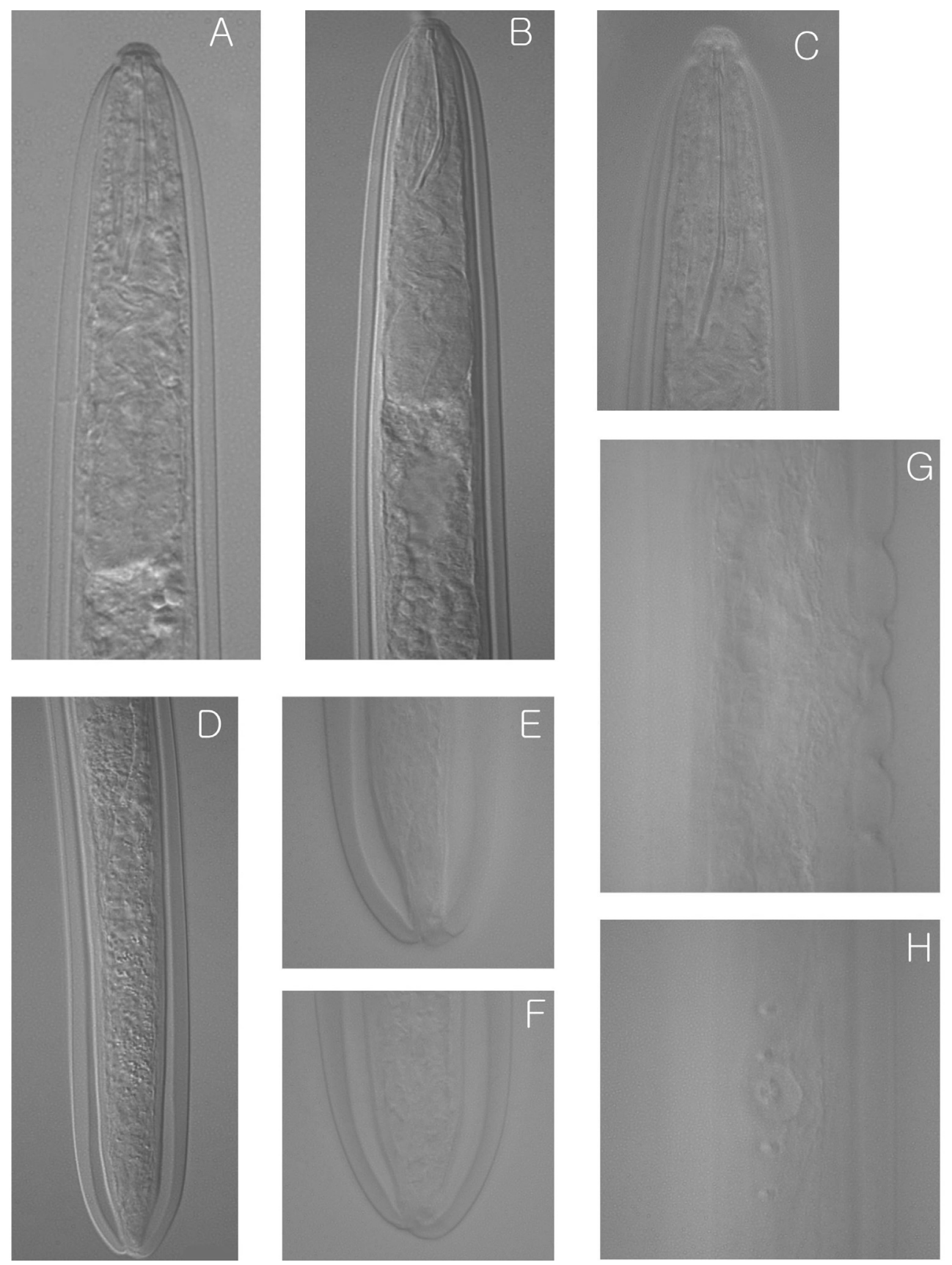

Fig. 3. Photomicrographs of Paratrichodorus porosus: A, B, C: Female anterior part; D, E, F: Female tail; G: Vulva region; H: Lateral view of vulva.

Male: not founded

Discussion on morphometric characters: The species was firstly reported as $P$. poresus in 1976 on Korea (Lee, 1976). That was a mistake of $P$. porosus. It was reported that $P$. porosus had various ventromedian pores anterior and posterior to the vulva (Allen, 1957; Siddiqi, 1962). Japanese specimens had frequently three advulvar pores (two anterior, one posterior; or one anterior, two posterior) (Decraemer, 1991). However Lee (1957) reported that $P$. porosus had four ventromedian pores. The species founded in Jeju province has also same number of ventromedian pores except one nematode (three ventromedian pores: two anterior, one posterior). As a result of this, it is assumed that P. porosus founded in Korea has generally four ventromedian pores. 
Locality and host: Seoqwipo city, Jeju province (Citrus unshiu Markovich).

This species has wide host range and distribution (Shishida, 1979; Decraemer, 1991). P. porosus was founded around soil at the root of soybean, garlic, chinese cabbage and maize in Korea (Lee, 1976). However, there was no the data of regional distribution.

\section{Literature Cited}

Allen, M.W. 1957. A review of the nematode genus Trichodorus with descriptions of ten new species. Nematologica, II: 32-62.

Bell, N.L. and R.N. Watson. 2001. Identification and host range assessment of Paratylenchus nanus (Tylenchida: Tylenchulidae) and Paratrichodorus minor (Triplonchida: Trichodoridae). Nematology. Vol. 3(6): 483-490

Choi, Y.E. 1996. Nematodes of Korea. 383pp. Ililsa, Daegu.

Decraemer, W. 1980. Systematics of the Trichodoridae (Nematoda) with keys to their species. Revue. Nematol. 3(1): 81-99.

Decraemer, W. 1991. Stubby root and virus vector nematodes: Trichodorus, Paratrichodorus, Allotrichodorus, and Monotrichodorus. pp. 587-625. Manual of agricultural nematology, eds. by W.R. Nickle. 1035pp. Marcel Dekker, New York.

Hooper, D.J. 1986. Handling, fixing, staining and mounting nematodes. pp. 59-80. Laboratory methods for work with plant and soil nematodes. eds. by J.F. Southey. 202pp. Commercial Colour Press, London.

Lee, Y.B. 1976. Two genera of Trichodoridae (Trichodoroidea: Nematoda) new to Korea. Kor. J. Pl. Prot., Vol. 15 No. 2: 75-78.

Shishida Y. 1979. Studies on nematodes parasitic on woody plants. 1. Family Trichodoridae (Thorne, 1935) Chark, 1961. Jap. J. Nematology. Vol. 9. 28-44.

Siddiqi, M.R. 1962. Trichodorus pakistanensis n. sp. (Nematoda: Trichodoridae) with observations on T. porosus Allen, 1957, $T$. mirzai Siddiqi, 1960, and T. minor Colbran, 1956, from India. Nematologica 8: 193-200.

Siddiqi, M.R. 1963. Trichodorus spp. (Nematoda: Trichodoridae) from Tunisia and Nicaragua. Nematologica 9: 69-75.

Siddiqi, M.R. 1973. Systematics of the genus Trichodorus Cobb, 1913 (Nematoda: Dorylaimida), with descriptions of three new species. Nematologica 19: 259-278.

(Received for publication December 3 2008;

revised December 3 2008; accepted December 8 2008) 